\title{
Requirements management methods: does the literature need an update?
}

\author{
Carina Campese, Janaina Mascarenhas Hornos da Costa \\ Universidade de São Paulo - USP \\ e-mails: carinacampese@yahoo.de; janainamhcosta@gmail.com
}

\begin{abstract}
There are many models of Product Development Process in the literature. Although these models have different phases, all activities must be formally managed through methods and requirements management processes. Such methods are cited in several sources in the literature, but there is still a lack of application of them in Brazilian companies. This may be due to the lack of information on these methods, such as their step-by-step, examples and objectives. Thus, this study aims to analyze the methods of requirements management through content analysis (that followed three main phases: preparation, organising and reporting), highlighting the methods focused on User-Centered Design (a trend approach), helping in the choice of application of the methods by companies. From this analysis, it is concluded that the literature still lacks more detail on the application of the requirements management methods, as well as a greater attention to the user-oriented methods.
\end{abstract}

Keywords: requirements management, user-centred design, product development process.

\section{Introduction}

There are many references in the literature about Product Development Process (PDP). Many models of PDP are suggested (e.g. PUGH, 1991; ROZENFELD et al., 2006; ULRICH; EPPINGER, 2012) and the importance of adopting a product development model is also discussed (ULRICH; EPPINGER, 2012). The phases and activities followed in the models differ subtly, but, in a general way, the first PDP phases cover activities to identify and understand the user needs and generate some product concepts. The user needs that are raised are transformed into user requirements and subsequently into product requirements (ROZENFELD et al., 2006). A User-Centred Design (UCD) approach can be applied during the PDP is User-Cented Design (UCD). This approach has expanded rapidly in 2017 and tends to grow even more (HOGUE, 2018).

The activities of the entire PDP should be managed through methods and requirements management processes (HOOD et al., 2008). These methods are cited in several sources in the literature (e.g. CMMI INSTITUTE, 2010; PAHL et al., 2007; ULRICH; EPPINGER, 2012), but there is still a low application of these methods in Brazilian companies (CARNEVALLI; CAUCHICK MIGUEL, 2009; MARQUES JUNIOR; PLONSKI, 2011). One of the causes may be the lack of information on these methods, such as their step-by-step and goals.

Thus, the present paper aims to analyze the methods of requirements management, highlighting those focused on User-Centered Design (UCD), helping in the choice of application of the methods by companies. In addition, this research seeks to answer the following question: "UCD is becoming a trend, but are the methods cited for requirements management focused on this?" This research followed the content analysis methodology proposed by Elo and Kyngäs (2008).

The paper is organized in six sections. In the first section, an introduction of the work is carried out. In the second section, a literature review about product development process and requirements management is presented. The third section describes how the study was carried out (methodology), and the following section (4) presents the results of the research. The fifth section contains the conclusions and final considerations of the study. Finally, all the references used are listed.

\section{The product development process}

The Product Development Process (PDP) can be defined as a sequence of sets of activities that a company adopts to design, manufacture, and market a product. This sequence begins in the perception of market opportunities and ends in the production, sale and delivery of a product (ULRICH; EPPINGER, 2012). According to the authors, having a PDP model is very useful for the company, as it guarantees the quality of the product and the coordination for the project team, offers a planning with phases and deliveries and a clear management, besides being able to contribute with a series of improvements for future projects through lessons learned. 
There are many PDP models that can be found in the literature. Although they are different in some respects (such as name and number of phases), most models start the process with the discovery of a market need (macro phase of pre-development). Some authors divide this macro phase into two phases: "market" and "specification" (PUGH, 1991), "strategic planning" and "project planning" (ROZENFELD et al., 2006), and "discovery: idea generation" and "stage 1: scoping" (COOPER, 2001). Other authors, however, suggest only one phase for the pre-product development: "opportunity identification and selection" (CRAWFORD; DI BENEDETTO, 2010), and "planning" (ULRICH; EPPINGER, 2012). Regardless of the name, all authors stress the importance of conducting market analysis and identifying new opportunities. The authors also suggest that a macro project planning be done, describing their objectives, constraints and timetable, for example. In this macro phase of pre-development, it is valid to emphasize that the stakeholders must be involved so that the project can align with the expectations of all those involved in it.

The macro phase of development contains steps for the concept development, for its detailing and for the preparation of its production. For the development of concepts, the phases named by the authors are: "concept design" (PUGH, 1991), "concept generation" and "concept/project evaluation" (CRAWFORD; DI BENEDETTO, 2010), "informational design" and the beginning of the "conceptual design" phase (ROZENFELD et al., 2006), "concept development" (ULRICH; EPPINGER, 2012), and "build business case" (COOPER, 2001). All authors indicate the generation of concepts based on the needs previously raised and also based on the needs of the user, which are raised at the beginning of this macro phase. The concepts are evaluated through technical and market feasibility and are selected.

In order to obtain a detailed description of the concepts generated, the following phases are suggested: "detail design" (PUGH, 1991), "development” (CRAWFORD; DI BENEDETTO, 2010), "conceptual design" and "detailed design" (ROZENFELD et al., 2006), "system-level design", "detail design" and "testing and refinement" (ULRICH; EPPINGER, 2012), and "development" and "testing \& validation" (COOPER, 2001). The concepts approved are detailed, the product architecture is elaborated and also its division into subsystems and components. In most models, the creation of prototypes to test the product is cited (CRAWFORD; DI BENEDETTO, 2010; ROZENFELD et al., 2006; ULRICH; EPPINGER, 2012) and, in some models, it is already thought about the manufacturing process (COOPER, 2001; CRAWFORD; DI BENEDETTO, 2010). It is worth mentioning that Ulrich and Eppinger (2012) indicate that the tests with the prototypes must be performed with consumers in an environment of real use, that is, the user's involvement in this phase is evident for the authors.

Ending this macro phase of development, the authors indicate activities for the manufacture of the product and its sale. The phases are: "manufacture" and "sell" (PUGH, 1991), "launch" (CRAWFORD; DI BENEDETTO, 2010), "production preparation" and "product launching" (ROZENFELD et al., 2006), "production ramp-up" (ULRICH; EPPINGER, 2012), and "launch" (COOPER, 2001). The specifications of machinery and manufacturing methods are defined, the product is produced and launched on the market.

After launching the product on the market, the macro phase of post-development begins in Rozenfeld et al. (2006) and Cooper (2001), in order to monitor the product in the market. The last phases of the models are named: "follow-up product/process" and "discontinue product on the market", and "post-launch review", respectively. The purpose of these phases is to verify if the product is in accordance with the needs and expectations of the customer and subsequently to withdraw the product from the market, doing an evaluation of its life cycle. For this verification suggested by the authors, integration with the user is also necessary.

It is evident then that user involvement is essential in product development, especially in its early stages, since it is very important to correctly understand user requirements (CHEMUTURI, 2013; HOOD et al., 2008; PRESSMAN, 2010). For this reason, the focus of this research is on the beginning of the macro phase of PDP development, where user needs are raised and understood and some product concepts are generated. The User-Centred Design (UCD) theory focuses on the user in product development and assists in the achievement of good usability of products (NORMAN; DRAPER, 1986 apud ABRAS; MALONEY-KRICHMAR; PREECE, 2004), thus, the application of UCD methods is indicated throughout the PDP.

The activities performed during the development of products must be managed through methods and processes of requirements management (HOOD et al., 2008). This practice of requirements management is performed in every company that offers a product or service, since every company has a relationship between customer and contractor, and customers have goals that need to be achieved through the product or service contracted. So, if the goal of satisfying the client's wishes exists, the requirements management occurs even implicitly (HOOD et al., 2008).

\subsection{Requirements management}

When user needs are obtained, it is desirable to group and sort them according to product life cycle phases (beginning, growth, maturity and decline) or by affinities. These organized, categorized, and structured needs are 
called user requirements. The user requirements, in turn, are translated by characteristics that the projected product must possess (ROZENFELD et al., 2006). The user requirements translated by features are the product requirements.

According to Marx and Paula (2011), a product requirement is a functionality that the product-system must have to satisfy a need or to achieve a stakeholder objective, being qualified by measurable conditions and constrained by constraints. The requirements can be classified as functional (or technical) or non-functional. Functional requirements are related to inputs and outputs of a system, while non-functional ones comprise aspects of quality and legal requirements.

The requirements' definition can be performed by a process of data collection, specification, data analysis (the judgment of the requirements is made based on quality criteria) and evaluation of requirements. The result of this process can lead to either acceptance or rejection of data, and in the second case, the whole process is redone (HOOD et al., 2008).

The management of all requirements received or generated by the project team (whether functional or non-functional) is called Requirements Management (RM) (CMMI..., 2010) and is cited by Hood et al. (2008, p. 3) as " $[\ldots]$ a set of procedures that supports the development of requirements including planning, traceability, impact analysis, change management and so on".

$\mathrm{RM}$ is seen as a process that follows four steps: planning, organization, allocation and control (CHEMUTURI, 2013). However, the definition of requirements management adopted in this research is that it is a "set of activities that help the project team identify, control, and track requirements and changes to requirements at any time as the project proceeds". In this way, the actions that must be taken for the management of requirements are: elicitation (needs and requirements), elaboration (refinement of requirements), negotiation (prioritization), specification (detailing) and validation (revision and validation) (PRESSMAN, 2010, p. 124).

Requirement management is often cited in the literature in both software and hardware projects. For software development, this is a required aspect by CMMI Institute (2010). Many authors (e. g. CHEMUTURI, 2013; PRESSMAN, 2010; ROZENFELD et al., 2006) cite the importance of making requirements management also for hardware. By grouping and sorting user needs, you can check for similar needs, eliminating possible replications and those that are of little relevance to the project, which guides the team to focus on more important aspects. Another important aspect of organizing this information is that it is possible to find the requirements that really please and surprise users, and generate benefits that customers normally do not expect, adding value to the product (ROZENFELD et al., 2006).

A good application of RM ensures defined and consolidated requirements, serving as a solid and stable basis for the construction of the product architecture. Without this, it is possible that any failures are identified avoiding rework later in the product development process (HOOD et al., 2008). Thus, RM decreases the inherent risk in the development of a product, especially if it is totally new (ULRICH; EPPINGER, 2012). In addition, not having the need to redesign the project, the team increases the possibility of delivering the project on time and within the budget forecast (PRESSMAN, 2010). There are many methods suggested in the literature that support RM.

\section{Methodology}

To reach the objective of this study (to make an analysis of the requirements management methods), it was followed the content analysis method proposed by Elo and Kyngäs (2008). According to the authors, the content analysis is a technique of great relevance for reading and interpretation of documents, being used for both quantitative and qualitative analyzes. There are two ways to do a content analysis, using two paths: inductive or deductive. When you have a low level of knowledge about a subject, the inductive approach is most recommended. The deductive approach is most used when there is prior knowledge about the subject being analyzed and also a theory, which in turn is tested. Thus, the approach that was used in this research was the inductive one, and followed three steps.

In the first step, the preparation, the topic of analysis was selected: product development models and requirements management methods that support the generation of ideas. In order to understand the PDP theme and requirements management, a bibliographic review was carried out in eleven books considered as a reference: Andreasen, Hansen and Cash (2015); CMMI Institute (2010); Cooper (2001); Pahl et al. (2007); Rozenfeld et al. (2006); Ulrich and Eppinger (2012); Aurum and Wohlin (2005); Clark and Fujimoto (1991); Crawford and Di Benedetto (2010); Pugh (1991) and Creveling, Slutsky and Antis (2002). The choice for books (instead papers) was due to the fact that companies and professionals in the area of product development have more access to books in general and also because they have a greater detail of the methods.

In the second step, the organization stage, four activities were carried out. The first one (called open coding) was to annotate and select in the texts relevant information for this research (requirements management theory and requirements management methods), and then a grouping of all this collected information was performed (activity 2: coding sheets). The requirements management methods 
cited were cataloged in a worksheet and compared to each other according to their objectives. It was also identified the method description and how it is applied (its step-by-step). In total, 69 methods were identified. With this information, the methods were grouped into the following categories: requirements management methods for market analysis; user profile identification; user needs identification; concepts generation; and concept validation. The third activity performed in this step was a grouping. In addition to those that had already been created, a comprehensive set of methods was created. These methods were judged by us not as methods, but rather as approaches, and that can be used as a basis in many methods. The methods of this new group were then excluded from the analysis of this research. The last activity (categorization), still in the second step, was to perform a final spreadsheet with the categorized requirements management methods that would be analyzed in this research.

In the third step, of the results, the methods of the spreadsheet were analyzed (47 methods). For this analysis the level of detail that the authors have about the methods in their citations was taken into consideration. The result of this analysis was a table listing the requirements management methods with the highest level of detail found in the authors that cite such methods. To accomplish this detail level table, the content of the methods in each book was analyzed. It was judged whether the method was just quoted, whether there was any explanation as to what the method and its objectives were, whether there was any example of an application or even a template, and whether there was a step-by-step of how the method is applied.

\section{Results}

For the analysis, the methods mentioned by the authors in the early stages of the PDP were first raised. Some of them were considered very embracing and, for this reason, were disregarded from the analysis of this research. These methods, as well as their respective references, can be observed in Figure 1.

In total, 47 methods were analyzed, organized according to their objectives (market analysis, user profile identification, user needs identification, product requirements generation, concepts generation and concepts evaluation) (Table 1). The table presents the highest level of detail of the methods of all the authors that mention them.

Despite the importance of conducting a good market analysis at the beginning of product development to generate good project opportunities (BAXTER, 2000), only four methods for this purpose were listed, being only one very detailed (matrix analysis). This can be detrimental to the project team as it may not adapt to the detailed method and choose to do this activity informally.

Both the PDP models and the UCD theory emphasize the importance of identifying user needs (ABRAS; MALONEY-KRICHMAR; PREECE, 2004; ULRICH; EPPINGER, 2012). To do this, it is advisable to first know

\begin{tabular}{|l|l|}
\hline Method & References \\
\hline Interviews & $1,3,4,8,10,11$ \\
\hline Focus group & $3,6,10,11$ \\
\hline Questionnaire & $1,5,8,10$ \\
\hline Observation & $2,3,4,10,11$ \\
\hline Brainstorming & $2,3,5,8,9,10$ \\
\hline Lead users & $3,6,9,11$ \\
\hline Workshops & 1,5 \\
\hline Working groups & 5 \\
\hline Discussions & 4 \\
\hline CAD & 5,7 \\
\hline $\begin{array}{l}\text { Camping out with costumers } \\
\text { (or fly on the wall) }\end{array}$ & 6 \\
\hline
\end{tabular}

\begin{tabular}{|l|l|}
\hline Method & References \\
\hline Stakeholder analysis & 5 \\
\hline Sketches & 2,8 \\
\hline Survey & 10 \\
\hline Ethnography & 1 \\
\hline Integration tools & 5 \\
\hline Portfolio management & $3,9,10$ \\
\hline Delphi method & $3,5,9$ \\
\hline Demonstration of use & 5 \\
\hline Test with product & 6 \\
\hline Bubble chart & 3 \\
\hline
\end{tabular}

[1] Aurum and Wohlin (2005)

[2] Andreasen, Hansen and Cash (2005)

[3] Crawford and Di Benedetto (2010)

[4] Creveling, Slutsky and Antis (2002)
[5] CMMI (2010)

[6] Cooper (2001)

[7] Clark and Fujimoto (1991)

[8] Pugh (1991)
[9] Pahl et al. (2007)

[10] Rozenfeld et al. (2006)

[11] Ulrich and Eppinger (2012)

Figure 1. Disregarded methods for analysis. Source: Elaborated by the authors. 
Table 1. Methods analysis.

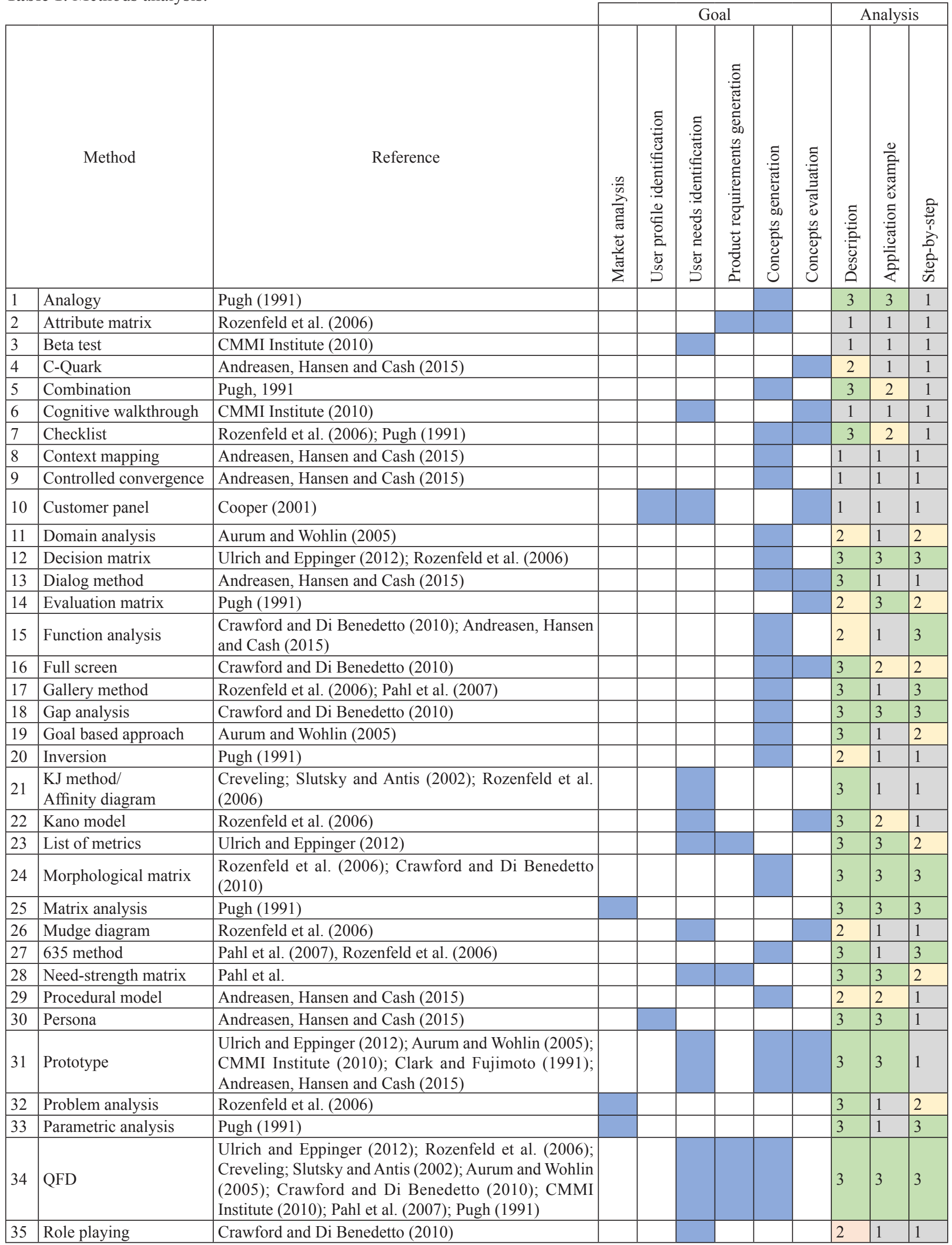


Table 1. Continued...

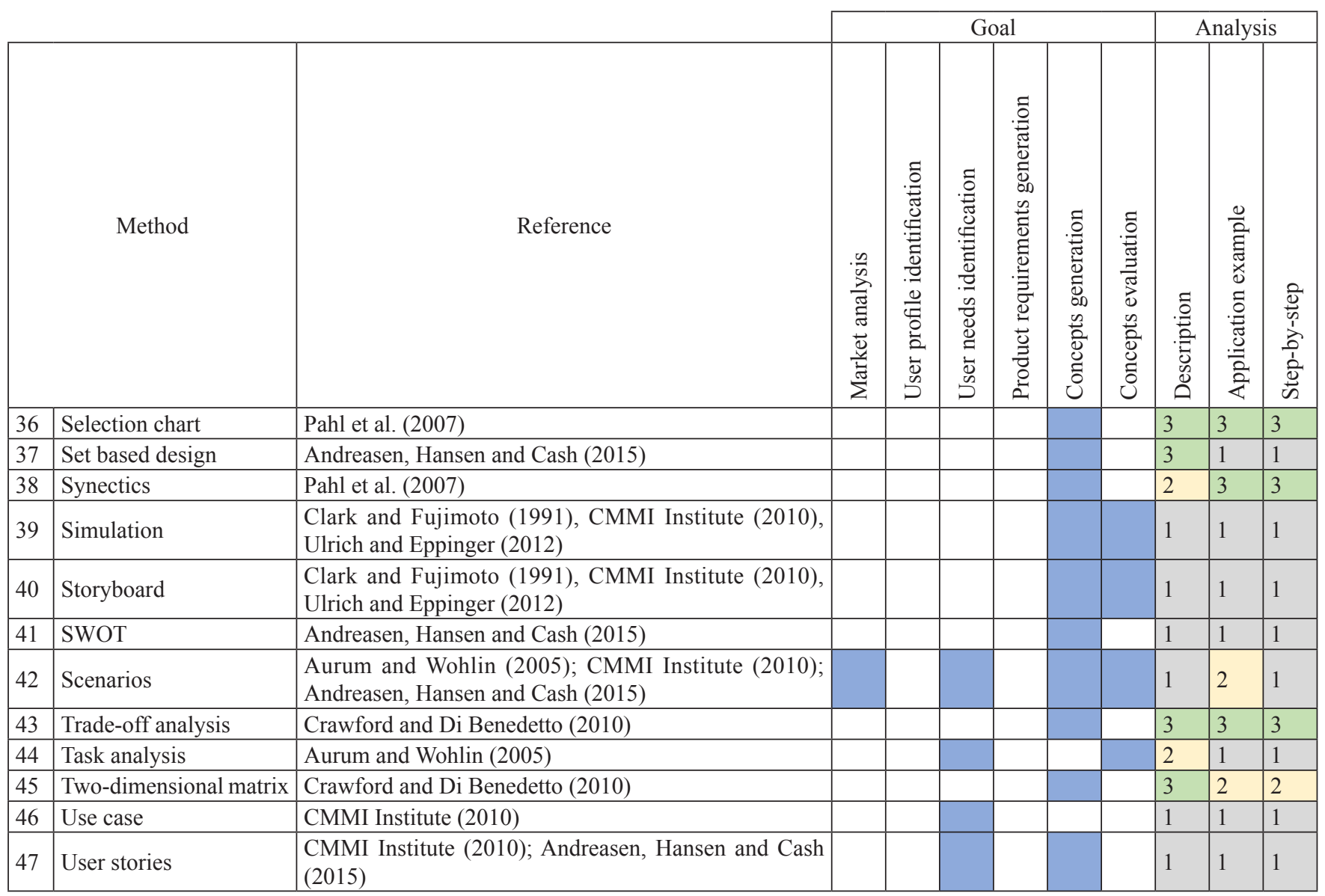

the profile of this user, facilitating the sharing of their information (KAYO, 2015). However, it is noted that only two methods were identified for user profile identification (persona and customer panel), and yet one of them has a low level of detail. The fact that it has only two methods to trace the user profile may be a reflection of the fact that UCD is a relatively new term (it appears in the literature in 1986 by Norman and Draper's book User-centered system design perspectives on human computer interaction [ABRAS; MALONEY-KRICHMAR; PREECE, 2004]), which has been applied in a more formal way recently, and this also justifies the fact that the most detailed method (persona) is more recent (from 2015). None of the sources that cite these methods presents their step-by-steps, which may further discourage their application.

To identify user needs, 15 methods were identified. Although it looks like a high number, only three have a higher level of detail (QFD, metrics matrix and needs matrix). Although they have this goal, when analyzing the methods themselves, it is realized that they only contain the user needs, and do not necessarily help in identifying them. The methods that really help with this inquiry are still lacking in detail.
It is also possible to note that there are many more methods for concepts generating (30 in total, 8 with more than one goal). However, only five have a good detailed application (gap analysis, trade-off analysis, morphological matrix, QFD and selection chart). One possible cause of the large number of citations of these methods and the little detail of them is that they can be in the texts only as examples, not being object of study of the authors.

It can be observed that for other methods, even though they are important, such as SWOT (ALVES et al., 2007), it lacks detailing, that is, the applicator would still have to seek information from this method in other sources.

Evaluate the concepts generated with specific methods and tools ensure the achievement of reliable results in the project (ROZENFELD et al., 2006). For the concepts evaluation, 14 methods were collected, but none of them presents a high average level of detail. In addition, none of them have a step-by-step application. This fact may contribute to a possible demotivation of the application of such methods. The lack of concept evaluation can lead to serious consequences for the PDP, such as the launch of a non-value-added product with some malfunction or failure, and project redesign. 
It can be observed that the most cited methods (with four references or more) (QFD and prototyping) have multiple objectives and also a good level of detail. This fact can bring benefits to those who choose to apply such methods because in addition to having some common goals, they can be applied together, bringing different contributions to the project.

In this study, it is considered that UCD methods are those that have user involvement (task analysis, scenarios, persona, customer panel, prototyping, cognitive walkthrough). Thus, of the 47 methods cited in the literature, only 6 are user-oriented, and yet, with little detail definition, examples of application and step-by-step.

For requirements management, elicitation, elaboration, negotiation, specification and validation must be carried out (PRESSMAN, 2010). With the analysis of the methods raised and the knowledge of their objectives, it can be affirmed that they attend the actions of a good requirements management, that is, there are methods proposed to carry out market analysis, profile and user needs identification (elicitation), product requirements and concepts generation (elaboration, negotiation and specification) and concept evaluation (validation). However, what is not clear in the citation of the methods is that they can be, and should be, applied iteratively (KARAT, 1996; VIITANIEMI et al., 2010).

It is observed that, from all the methods identified, only 12 of them are mentioned with a step-by-step. Having a step-by-step method is critical to guiding your application, leaving fewer doubts in your practitioners and encouraging them to use such a method.

\section{Conclusions}

Through the analysis of the management requirements methods cited in the literature, applied in the beginning of the product development, it can be concluded that there is a greater dissemination of the methods to generate concepts, while the less cited ones are for identification of the user profile and market analysis. Because they were citations in the literature, it was expected a greater level of detail, especially in explaining the method goals and the step-by-step of how to apply it.

It is important to emphasize the importance of methods with greater descriptions in literature, since they are a source for professionals in the area of product development. Without this information, the practitioner may not understand the importance of applying a specific method and may even be discouraged from applying it, leaving the PDP more informal and biased. A book that focused more on methods than on PDP phases would be very useful to the industry.
In addition, there is a demand for textbooks for methods that focus on user involvement, a trend theme in the development of both products and systems.

\section{Acknowledgements}

This research was supported by the Coordination of Improvement of Higher Education Personnel (CAPES).

\section{References}

ABRAS, C.; MALONEY-KRICHMAR, D.; PREECE, J. User-centered design. In: BAINBRIDGE, W. (Ed.). Encyclopedia of human-computer interaction. Thousand Oaks: Sage Publications, 2004. v. 37, n. 4, p. 445-456.

ALVES, I. et al. Aplicação do modelo e análise SWOT no diagnóstico estratégico de uma propriedade rural especializada em recria e engorda de bovinos de corte. Revista Administra-Ação, v. 4, p. 22-39, 2007.

ANDREASEN, M. M.; HANSEN, C. T.; CASH, P. Conceptual design: interpretations, mindset and models. New York: Springer, 2015. http://dx.doi.org/10.1007/978-3-31919839-2.

AURUM, A.; WOHLIN, C. Engineering and managing software requirements. Berlin: Springer, 2005. http:// dx.doi.org/10.1007/3-540-28244-0.

BAXTER, M. Projeto de produto: guia prático para o design de novos produtos. 2. ed. São Paulo: Edgard Blucher, 2000.

CARNEVALLI, J. A.; CAUCHICK MIGUEL, P. A. Empresas de referência na utilização do desdobramento da função qualidade. Revista Produto \& Produção, v. 10, n. 1, p. 1-18, 2009.

CHEMUTURI, M. Requirements engineering and management for software development projects. New York: Springer, 2013. http://dx.doi.org/10.1007/978-14614-5377-2.

CLARK, K. B.; FUJIMOTO, T. Product development performance: strategy, organization, and management in the world auto industry. Boston: Harvard Business School Press, 1991.

CMMI INSTITUTE. CMMI ${ }^{\circledR}$ for development, version 1.3 . Pittsburgh: Software Engineering Institute, 2010.

COOPER, R. G. Winning at new products: accelerating the process from idea to launch. 3th ed. Cambridge: Perseus Publishing, 2001.

CRAWFORD, C. M.; DI BENEDETTO, C. A. The new products management. 10th ed. New York: McGrawHill, 2010.

CREVELING, C. M.; SLUTSKY, J.; ANTIS, D. Design for Six Sigma in technology and product development. Upper Saddle River: Prentice Hall Professional, 2002. 
ELO, S.; KYNGÄS, H. The qualitative content analysis process. Journal of Advanced Nursing, v. 62, n. 1, p. 107-115, 2008. http://dx.doi.org/10.1111/j.1365-2648.2007.04569.x.

Hogue, J. A11y, Chatbots, and AI, Oh My! Usercentered design trends for 2018. Providence: Oomph, 2018. Available from: <https://www.oomphinc.com/ notes/2018/01/user-centered-design-trends-2018/>. Access in: 11 Mar 2018.

HOOD, C. et al. Requirements management: the interface between requirements development and all other systems engineering processes. Berlin: Springer, 2008.

KARAT, J. User centered design: quality or quackery? Magazine Interaction, v. 3, n. 4, p. 18-20, 1996. http:// dx.doi.org/10.1145/234813.234814.

KAYO, R. O que é mapa de empatia e para que serve? 2015. Available from: <http://ramonkayo.com/conceitose-metodos/o-que-e-mapa-de-empatia-e-para-que-serve $>$. Access in: 7 July 2015.

MARQUES JUNIOR, L. J.; PLONSKI, G. A. Gestão de projetos em empresas no Brasil: abordagem "tamanho único"? Gestão \& Produção, v. 18, n. 1, p. 1-12, 2011. http://dx.doi.org/10.1590/S0104-530X2011000100001.
MARX, Â. M.; PAULA, I. C. Proposta de uma sistemática de gestão de requisitos para o processo de desenvolvimento de produtos sustentáveis. Revista Produção, v. 21, n. 3, p. 417-431, 2011. http://dx.doi.org/10.1590/S010365132011005000041 .

PAHL, G. et al. Engineering design: a systematic approach. 3th ed. New York: Springer, 2007. http://dx.doi. org/10.1007/978-1-84628-319-2.

PRESSMAN, R. S. Software engineering: a practitioner's approach. 7th ed. New York: McGraw-Hill, 2010.

PUGH, S. Total design: integrated methods for successful product engineering. Wokingham: Addison-Wesley, 1991.

ROZENFELD, H. et al. Gestão de projetos em desenvolvimento de produtos. São Paulo: Saraiva, 2006.

ULRICH, K. T.; EPPINGER, S. D. Product design and development. 5th ed. McGraw-Hill, 2012.

VIITANIEMI, J. et al. Integration of user-centred design and product development process within a virtual environment. Finland: VTT Technical Research Centre of Finland, 2010. 